\title{
28 Research Soure \\ Photoinactivation Efficiency of Cationic Porphyrin Derivatives Against Multidrug-Resistant Wound Pathogens
}

\author{
Ayşe AKBIYIK ( $\nabla$ ayse.akbiyik@ikcu.edu.tr ) \\ Izmir Katip Çelebi University https://orcid.org/0000-0003-0513-5433 \\ Hüseyin TAŞLI \\ Ege University \\ Nermin TOPALOĞLU \\ İzmir Katip Çelebi University \\ Vildan ALPTÜZÜN \\ Ege University \\ Sülünay PARLAR \\ Ege University

\section{Selçuk KAYA} \\ İzmir Katip Çelebi University
}

\section{Research Article}

Keywords: Antimicrobial photodynamic therapy, photoinactivation cationic porphyrin derivatives, multidrugresistant, Pseudomonas aeruginosa, Escherichia coli, Acinetobacter baumannii, Klebsiella pneumoniae.

Posted Date: September 27th, 2021

DOI: https://doi.org/10.21203/rs.3.rs-883644/v1

License: (1) This work is licensed under a Creative Commons Attribution 4.0 International License. Read Full License 


\section{Abstract}

The photoinactivation efficiency of antimicrobial photodynamic therapy (aPDT) with cationic porphyrin derivatives (CPDs) against multidrug-resistant (MDR) bacterial strain was assessed. MDR bacterial strains including Pseudomonas aeruginosa, Escherichia coli, Acinetobacter baumannii, and Klebsiella pneumoniae were used. The CPDs named PM, PE, PN, and PL were synthesized as a photosensitizer (PS). A diode laser with a wavelength of $655 \mathrm{~nm}$ was used as a light source. Photoinactivation efficiency of the combinations formed with different energy density $\left(50,100\right.$, and $150 \mathrm{~J} / \mathrm{cm}^{2}$ ) and PS concentrations (ranging from $3.125 \mu \mathrm{M}$ and $600 \mu \mathrm{M}$ ) on each bacterial strain were evaluated. Toxicity of the aPDT combinations that showed a strong photoinactivation on the bacterial strains and dark toxicity of PSs and were evaluated on fibroblasts cells. In the aPDT experiments, survival

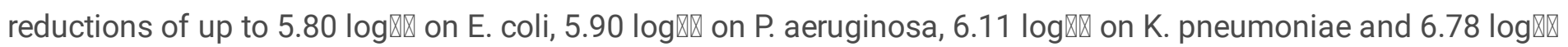
on A. baumannii were obtained. There was an increase in the photoinactivation efficiency in parallel with increasing the energy density, and the best effect seen at an energy density of $150 \mathrm{~J} / \mathrm{cm} 2$. PL did not show any toxic effect on fibroblasts. However, other PSs were toxic in fibroblasts at high concentrations. In this research, which reflected the results of in vitro experiments, aPDT provided potent photoinactivation against MDR clinical isolates. The research results lead to an in vivo wound model study of aPDT with CPD infected with an MDR clinical isolate.

\section{Introductions}

Critical colonization or infection is a common problem in chronic wounds such as surgical site infections, burns, diabetic foot, venous leg, and pressure ulcers. Similarly, critical colonization ( $10^{5}$ colony forming units (CFU)/gram tissue) defined as the colonization of pathogenic microorganisms in the wound without clinical symptoms or pathological reactions, is an important problem frequently experienced. Critical colonization and infection on wounds retard tissue healing. The infection or critical colonization is not limited to the wound surface, progresses to deep tissues, and causes serious complications such as osteomyelitis, bacteremia, and sepsis. Source of infection on the wounds is usually polymicrobial. However, bacteria such as multidrug-resistant (MDR) Staphylococcus aureus, Escherichia coli, Pseudomonas aeruginosa, Acinetobacter baumannii, Klebsiella pneumoniae are often isolated (Aftab et al. 2014; Braga et al. 2013; Siddiqui and Bernstein 2010).

Healing of the infected wounds is directly related to the reduction of microbial colonization on the wound. Today, antiseptics and antimicrobials are recommended to reduce the critical colonization or eliminate the infection (Nasir et al. 2016; National Pressure Ulcer Advisory Panel 2014). However, there are some problems that limit the use of these antimicrobials. Some antimicrobials are not selective to microorganisms and can damage healthy tissue. Using for more than two weeks may harm the granulation and epithelialization process. Some antimicrobials may have limited penetration to the wound tissue and biofilm layer and remain insufficient to heal the deep wound infection (Daeschlein et al. 2010; Norman et al. 2016). Therefore, the search for novel methods to accelerate wound healing has become inevitable.

Antimicrobial photodynamic therapy (aPDT) is a treatment method based on the principle of killing microbial cells using a non-toxic dye or a photosensitizer (PS) and a harmless visible light that stimulates PS. aPDT shows its antimicrobial efficacy with the reactive species formed as a result of chemical and physical reactions that occur in two different ways including Type I and Type II. The reactive species formed cause damage to bacterial DNA, cytoplasmic membrane, enzyme, and transport systems and provide antimicrobial activity (Dai, Huang, and

Loading [MathJax]/jax/output/CommonHTML/fonts/TeX/fontdata.js 11). Efforts to find an ideal PS for aPDT, such as a 
nontoxic, light-activated, broad-spectrum photoinactivation effect and high singlet oxygen quantum yield are ongoing. Porphyrin derivatives have the potential to be an ideal PS.

Porphyrins are macro-cyclic aromatic molecules formed by connecting four pyrrole rings together with methylene $(-\mathrm{HC}=)$ bridges (Nitzan and Ashkenazi 2001). Porphyrins, which originated from protoporphyrin IX (PPIX), are isolated from natural environments such as body fluids and feces of animals, eggshells, and feathers of birds. Porphyrins are of vital importance for living, including bacteria. Heme (Fe $₫ \mathrm{PPIX}) /$ hemin (Fe $\left.{ }^{3} \mathrm{PPIX}\right)$ compound in the structure of hemoglobin and myoglobin is involved in important biological processes, such as oxygen binding, oxygen transfer, nitric oxide synthetase and transfer of electrons in cytochromes. Most bacteria meet their iron needs from Fe ${ }^{2}$ PPIX. Gram-positive and Gram-negative bacteria have Fe ${ }^{2+} \mathrm{PPIX}$ uptake mechanisms, including TomB and ExbBD proteins (Stojiljkovic 2001). Natural or porphyrin derivatives using conjugates such as porphyrincellulose-nanocrystals or antibiotics can easily penetrate in bacteria by $\mathrm{Fe}^{2} \bigotimes \mathrm{PPIX}$ acquisition mechanisms and demonstrate through several chemical processes such as transferring electrons, catalyzing peroxidase and oxidase reactions, absorbing photons, production of reactive oxygen species (Carpenter et al. 2012; Lippert et al. 2017).

Cationic porphyrins show their antimicrobial activity through type II reaction mechanism. Single oxygen ( $\left.{ }^{1} \mathrm{O} \nabla\right)$ formed by the transfer of the energies of light-induced cationic porphyrins to molecular oxygen reacts with structures such as phospholipids, peptides, and sterols in the cell wall and cell membrane and cause cell death (Alves et al. 2014; Amos-Tautua, Songca, and Oluwafemi 2019; Reddi et al. 2002; Tavares et al. 2011). This result has been confirmed in the studies using CPDs such as $\mathrm{T}_{4}$ MPyP (Reddi et al. 2002), 5,10,15,20-tetrakis (1-methylpyridino)-21H, 23H-porphine, tetra-p-tosylate salt (TMP) (Collins et al. 2010), Tetra-Py+-Me, Tri-SPy+-Me-PF (Alves et al. 2013), meso-tetra(pyren-1-yl)porphyrin (TPyP), metallo-tetrapyrenylporphyrins NiTPyP, CuTPyP and ZnTPyP compounds (Zoltan et al. 2010), tetracationic zinc(II) tetrapyridinoporphyrazine (Ragàs et al. 2013), mesoimidazolium-substituted porphyrin derivative (ImP) and pyridinium-substituted porphyrin derivative (PyP) (Prasanth et al. 2014), 5,10,15,20-tetrakis(4-nitrophenyl)porphyrin (TNPP) and zinc porphyrin complex (ZnTNPP) (Rahimi et al. 2016), porphyrin - magainin conjugate and porphyrin - buforin conjugate (Dosselli et al. 2014). In this current study, different from previous studies, the aim was to obtain a broad spectrum photoinactivation efficiency on MDR clinical isolates with the CPDs synthesized by us. In our previous study, a strong photoinactivation was obtained on methicillin-resistant Staphylococcus aureus (MRSA) (Taslı et al. 2018). The goals in this present study in which multi-drug resistant Gram negative bacteria were used can be listed as follows:

- To determine the light energy density and PS concentration ranges that create photoinactivation on the strain selected representing each species;

- To investigate the photoinactivation of the combinations of energy density and PS concentration providing strong photoinactivation on other strains of each species.

- To investigate the toxicity of all aPDT combinations with photoinactivation effect on fibroblasts.

\section{Methods}

\section{Bacteria}

A total of 21 clinical isolates including $P$. aeruginosa $(\mathrm{n}=3)$, E. coli $(\mathrm{n}=2)$, A. baumannii $(\mathrm{n}=14), K$. pneumoniae $(\mathrm{n}$ = 2) were used. These clinical isolates with MDR were obtained from İmir Katip Çelebi University Faculty of Medicine, Microbiology Laboratory. Antibiotic susceptibilities of bacteria using routine tests according to Clinical 
Laboratory Standards Institute-2018 (CLSI-2018) recommendations were evaluated (Institute 2018), and the results was as shown in supplementary 1.

\section{Photosensitizer}

CPDs named PM, PE, PN and, PL were synthesized by researchers at Ege University Faculty of Pharmacy Pharmaceutical Chemistry Department. The chemical structure and absorbance values of the CPDs which previously evaluated for aPDT efficacy on MRSA by researchers (Taslı et al. 2018) were shown in Fig. 1a. CPDs can absorb a wavelength in the broad spectrum varying from 250 to $800 \mathrm{~nm}$ and, the maximum light absorption was at $422 \pm 3 \mathrm{~nm}$ (Fig. 1b).

Chemistry: The infrared (IR) spectra of the compounds were monitored by attenuated total reflectance (ATR) (PerkinElmer Spectrum 100 FT-IR, Waltham, MA, USA). ${ }^{1} \mathrm{H}$ NMR spectra were recorded on an Agilent $600 \mathrm{MHz}$ Premium COMPACT NMR spectrometer (Santa Clara, CA, USA) by using tetramethylsilane (TMS) as an internal standard and DMSO- $\mathrm{d}_{6}$ as a solvent. Chemical shifts were measured in parts per million $(\delta)$. The $J$ values were given in $\mathrm{Hz}$. Abbreviations for data quoted are: s, singlet; $d$, doublet; t, triplet; q, quartet; quin, quintet; sxt, sextet. All reagents and solvents were of reagent-grade quality and obtained from commercial suppliers (Sigma, Acros and Merck). Elemental analyses (C, H, N) were performed by Leco TruSpec Micro (Leco, St. Joseph, MI, USA).

General procedure for the synthesis of the final compounds: CPDs were prepared according to the method of Gomes et al., 2011 (M. Gomes et al. 2011). Excess of the corresponding alkyl halide (iodomethane, ethyl bromide, propyl bromide, 3-Bromo-1-propanol) (65 mmol) was added to a suspension of 5,10,15,20-tetrakis(4pyridyl)porphyrin $(120 \mathrm{mg}, 193.9 \mu \mathrm{mol})$ in DMF (30 mL). After refluxing for 1-8 $\mathrm{h}$, the mixture was cooled to room temperature and the obtained precipitate was filtered and washed with diethyl ether or ethanol. The crude product was taken in acetone-water (1:1) and then filtered, washed with acetone. The structures of the final compounds were confirmed by FT-IR, $1 \mathrm{H}$ NMR, and elemental analysis. The purity levels of compounds were determined by elemental analysis $(\mathrm{C}, \mathrm{H}, \mathrm{N})$, and the results were within $\pm 0.4 \%$ of the calculated values. Spectral and elemental analysis data of the compounds were reported in the supporting information (Supplementary 2).

Minimal inhibitory concentrations (MIC) of the CPDs for E.coli-1, P. aeruginosa-1, K. pneumoniae-1, and $A$. baumannir-1 were evaluated by the micro-dilution method according to CLSI-2018 to determine antimicrobial activity and predict maximal PS concentration levels that could be used in photoinactivation experiments (Institute 2018). The MIC experiments evaluated at Ege University Pharmaceutical Microbiology Laboratory was done as described in the study (Taslı et al. 2018). $1 \mathrm{~mL}$ of Tryptic Soy Broth (TSB) containing bacteria was centrifuged (3000 rpm at $4{ }^{\circ} \mathrm{C}$ for 10 minutes) and the supernatant was discharged without touching the pellet. $1 \mathrm{ml}$ of phosphate buffer saline (PBS) was added onto the pellet remaining at the bottom and suspended. Bacterial suspensions were adjusted to standard McFarland $0.5\left(1.5 \times 10^{8} \mathrm{CFU} / \mathrm{mL}\right)$ turbidity and further diluted to give a final inoculum size of $5 \times 10^{5} \mathrm{CFU} / \mathrm{mL}$ per well. $50 \mu \mathrm{L}$ of Mueller Hinton Broth (MHB) was transferred to each well of 96 well plates. The two-fold serial dilutions were made by adding $50 \mu \mathrm{L}$ PS dissolved in PBS/antibiotic to the first wells of the plates. In the evaluation, ciprofloxacin was adjusted from an initial concentration of $16 \mu \mathrm{g} / \mathrm{mL}$ to a final concentration of $0.016 \mu \mathrm{g} / \mathrm{mL}$ and, PSs were adjusted from an initial concentration of $5.000 \mu \mathrm{g} / \mathrm{mL}$ and final concentrations of $2.441 \mu \mathrm{g} / \mathrm{mL}$. $50 \mu \mathrm{L}$ of bacteria suspension $\left(5 \times 10^{5} \mathrm{CFU} / \mathrm{mL}\right)$ was added to each well of the plates and, the plates were allowed to incubate at $37^{\circ} \mathrm{C}$ for $16-18 \mathrm{~h}$. After the incubation, the MIC values of the CPDs were determined by calculating the lowest compound concentrations that prevent the growth of bacteria. All

Loading [MathJax]/jax/output/CommonHTML/fonts/TeX/fontdata.js ated at least three times.

Page $4 / 22$ 
A diode laser with a wavelength of $655 \mathrm{~nm}$ was used as a light source (PSU III.LED; Changchun New Industries Optoelectronics Co. Ltd., Changchun, China). The distance between the optical plate and the fiber tip was $8.7 \mathrm{~cm}$, and the light illuminated an area of $3.14 \mathrm{~cm}^{\square}$ on the optical plate from this distance. The output power of light was measured as 41.5 milliwatts $(\mathrm{mW})$ at the plate surface.

Photoinactivation experiments

Photoinactivation experiments were carried out in two stages at Izmir Katip Çelebi University Central Research Laboratories Biomedical Optics and Laser Applications Laboratory. Firstly, bacterial photoinactivation evaluation was carried out by using combinations of different energy density $\left(\mathrm{J} / \mathrm{cm}^{2}\right)$ and PS concentrations $(\mu \mathrm{M})$ on a single clinical isolate representing each species. Because clinical isolates of each species had a similar antibiotic resistance profile (Supplementary 1), randomization was used to select representative isolates. In these pioneering experiments, the photoinactivation efficiency of aPDT combinations on representative clinical isolates was determined. The combinations for each PS were determined as follows: aPDT experiments were started with low energy density and PS concentration. The energy density was kept constant and the PS concentration gradually increased until a strong antimicrobial activity was achieved. After this stage, the energy density was increased and the PS concentrations were gradually reduced until limited antimicrobial efficacy was developed. In determining the maximum PS concentration that can be used in the combinations, the MIC values of PSs were taken into account. In the second step, the photoinactivation effect on the other strains of the bacteria species was evaluated for the combination that had a strong photoinactivation on the selected bacterial strain. The following groups were formed in each of the aPDT experiments:

- Laser group (L) where light was applied alone,

- PS group where PS was applied alone,

- aPDT group where both the light and PS were applied together,

- Control group (C) where PBS was applied alone.

$50 \mu \mathrm{L}$ of the bacterial suspension that adjusted to standard McFarland $0.5\left(1.5 \times 10^{8} \mathrm{CFU} / \mathrm{mL}\right)$ turbidity was transferred to specific wells of each of 96 well plates identified as PS, aPDT, L, and C. $50 \mu \mathrm{L}$ PS from the stock suspensions at specific concentrations was added to wells of the PS and aPDT group plates containing bacteria. $50 \mu \mathrm{L}$ of PBS was added to the wells of the $\mathrm{L}$ and $\mathrm{C}$ group plates with bacteria. All four groups were incubated for $15 \mathrm{~min}$ at room temperature. The aPDT and L group plates were exposed to light. After light exposure, bacterial suspensions in all groups were diluted by serial dilution using PBS. $100 \mu \mathrm{L}$ of aliquot was taken from the dilutions and plated on tryptic soy agar and left for an overnight incubation in the dark area at $37^{\circ} \mathrm{C}$. After incubation, bacterial survival was calculated at CFU/mL. Each experiment was repeated three times in triplicate.

Toxicity on the fibroblast cells

These experiments were carried out as described in study (Topaloğlu et al. 2020) at Izmir Katip Çelebi University Loading [MathJax]/jax/output/CommonHTML/fonts/TeX/fontdata.js er Applications Laboratory. A healthy mouse skin 
fibroblast cell line (L929) was used in the study. The cells were cultured in $75 \mathrm{~cm}^{\natural}$ tissue culture flasks in Dulbecco's Modified Eagle's Medium (DMEM) (Sigma Aldrich, Germany) solution, containing 1\% L Glutamine (Gibco, USA), 10 \% Fetal Bovine Serum (FBS) (Gibco, USA) solution, and 1\% Penicillin/Streptomycin (Gibco, USA). These cells were incubated in a humidified environment containing 95\% air and 5\% CO $\otimes$ until they form a confluent culture in a single layer. The cells reaching $80 \%$ confluence were washed with PBS and trypsinized using $0.05 \%$ trypsin and $0.02 \%$ ethylenediaminetetraacetic acid (EDTA) (Biological Industries, Israel). $2 \times 10^{4}$ fibroblast cells were seeded into each well of 96 -well plates and allowed to incubate at $37^{\circ} \mathrm{C}$ for $24 \mathrm{~h}$ so that the cells adhere to the wells of the plate. Then the cell culture medium was discarded and the experimental process continued as described in the groups below.

The dark toxicity of the concentrations ranging from 25 to $600 \mu \mathrm{M}$ for $\mathrm{PM}, 3.125$ to $400 \mu \mathrm{M}$ for PE, PN, and PL on the fibroblast was performed using $15 \mathrm{~min}$ and $24 \mathrm{~h}$ incubation. In the experiment, $100 \mu \mathrm{L}$ PS suspension from stock suspension dissolved at specific concentrations in cell culture medium for dark toxicity groups was transferred to plate wells containing fibroblasts. $100 \mu \mathrm{L}$ cell culture medium without PS was transferred to control group plate wells. The plates wrapped with aluminum foil to create a dark environment and allowed to incubate at $37^{\circ} \mathrm{C}$ incubate for $15 \mathrm{~min}$ or $24 \mathrm{~h}$.

The toxicity of aPDT on the fibroblast cells was performed using $15 \mathrm{~min}$ and $24 \mathrm{~h}$ incubation. $100 \mu \mathrm{L}$ from PS suspension dissolved at specific concentrations in cell culture medium was transferred to plate wells containing fibroblasts cells (Combinations were as in Fig. 7b). $100 \mathrm{ml}$ cell culture medium without PS was placed in the control and light group plate wells containing fibroblast cells. The plates wrapped with aluminum foil to create a dark environment and allowed to incubate at $37^{\circ} \mathrm{C}$ incubate for $15 \mathrm{~min}$. Phototoxicity or $\mathrm{L}\left(50 \mathrm{~J} / \mathrm{cm}^{2}, 100 \mathrm{~J} / \mathrm{cm}^{2}\right.$, and $150 \mathrm{~J} / \mathrm{cm}^{2}$ ) and aPDT groups were irradiated at an appropriate energy density with a diode laser. Control and PS groups were taken from the incubator but not exposed to ambient light or laser. After the light application to aPDT or light groups was finished, all the plates wrapped with aluminum foil again and allowed to incubate at $37^{\circ} \mathrm{C}$ incubate for $15 \mathrm{~min}$ or $24 \mathrm{~h}$.

Following, cell culture medium or PSs added to the plate wells were removed. Cells in the wells were washed with PBS. $100 \mu \mathrm{L}$ MTT (4.5-dimethylthiazol-2-yl)-2.5-diphenyl tetrazolium bromide ( $5 \mathrm{mg} / \mathrm{mL}$ ) (Sigma, St. Louis, MO, USA) was added to each well. After $2 \mathrm{~h}$ of incubation, the formazan crystals were dissolved with $100 \mu \mathrm{L}$ of DMSO, and the absorbance was measured at $570 \mathrm{~nm}$ with a microplate reader (iMark, Bio-Rad Lab., USA.). The absorbance values were used to determine the change in survival in fibroblast cells. Control groups were used for each experiment. Each experiment was repeated three times in triplicate.

Data analysis and Evaluation

In the photoinactivation experiments, the calculations were done as described below: First, bacterial survival in $\mathrm{CFU} / \mathrm{mL}$ for each plate was calculated according to formula 1.

\section{Formula 1}

$\mathrm{CFU} / \mathrm{mL}=$ Number of colonies per $m L$ on the plate $\times$ Total dilution factor

The control group was taken as a reference for determining survival reduction of the aPDT, PS, or L groups. Survival reductions were calculated as logarithmic as shown in formula 2.

Loading [MathJax]/jax/output/CommonHTML/fonts/TeX/fontdata.js 


$$
\text { Reduction }=\log _{10}\left(\frac{\text { NumberofcoloniespermLinthecontrolgroup }}{\text { NumberofcoloniespermLintheapplicationgroup }}\right)
$$

For the toxicity on the fibroblast cells, the calculations were done as follows. The control group was taken as a reference for determining the toxic effect of dark toxicity, phototoxicity, or aPDT applications on fibroblast cells. Percentage changes of the fibroblast cell survival based on the absorbance values of the groups were calculated according to formula 3.

Formula 3

Cellviablility $(\%)=\frac{(\text { Absorbancevalueofcontrolgroup }- \text { Absorbancevalueoftheapplicationgroup }) \times 100}{\text { Absorbancevalueofthecontrolgroup }}$

SPSS 16.0 was used for data analysis. "Paired sample t-test" was used to determine the differences of laser or aPDT groups compared to the control. In the comparisons, differences with $p<0.05$ were accepted as statistically significant.

\section{Results}

Antibacterial activity

The MIC values of CPDs and ciprofloxacin for bacterial strains ranged from 850.40 to $>7365.51 \mu \mathrm{M}$ (Table 1).

Photoinactivation of the bacterial strains

In the experiments, the photoinactivation efficiency of the combinations (energy density and PS concentration) on the clinical isolates representing the species for each PS was determined. In these preliminary experiments, the combinations with low PS concentration that provided strong photoinactivation on the clinical isolates were selected. In secondary experiments, the photoinactivation efficiency of combination selected by pioneering experiments was examined on other clinical isolates of the species.

Figure 2a shows the photoinactivation efficiency of the aPDT combinations on E.coli-1. A strong photoinactivation was not seen at any of the PM concentrations combined with $50 \mathrm{~J} / \mathrm{cm}^{2}$. For the other three PSs, $\left[50 \mathrm{~J} / \mathrm{cm}^{2}-400 \mu M\right]$ combination created a strong photoinactivation. For all four PSs, $\left[150 \mathrm{~J} / \mathrm{cm}^{2}-200 \mu \mathrm{M}\right]$ combination provided a survival reduction ranging from 4.73 to $5.71 \log \bigotimes$. The same combination as seen in Fig. $2 b$ showed strong photoinactivation effect on $E$. coli-2. The survival reductions in the aPDT groups using PM, PE, PN, and PL were

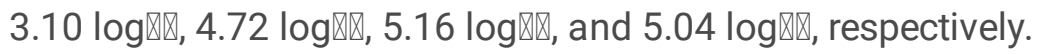

Figure 3 shows the photoinactivation results of the aPDT combinations on $P$. aeruginosa. The combinations that produced strong photoinactivation on $P$. aeruginosa-1 were $\left[100 \mathrm{~J} / \mathrm{cm}^{2}-600 \mu \mathrm{M}\right]$ for $\mathrm{PM},\left[100 \mathrm{~J} / \mathrm{cm}^{2}-300 \mu \mathrm{M}\right]$ for PE and PN, and $\left[100 \mathrm{~J} / \mathrm{cm}^{2}-100 \mu \mathrm{M}\right]$ for PL. These combinations created survival reductions ranging from 4.07 to 5.02 1 Loading [MathJax]/jax/output/CommonHTML/fonts/TeX/fontdata.js 
3.82 to $5.90 \log \mathbb{} \mathrm{Q}$ in other three $P$. aeruginosa isolates. For both $\mathrm{PE}$ and $\mathrm{PN}$, the survival reduction in all three

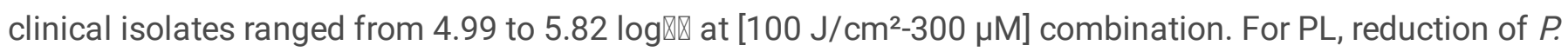
aeruginosa isolates reached $5.04 \log \varangle \mathbb{Z}$ at $\left[100 \mathrm{~J} / \mathrm{cm}^{2}-100 \mu \mathrm{M}\right]$ combination.

For K. pneumoniae-1, the combinations with strong photoinactivation for PM, PE, PN, and PL were $\left[150 \mathrm{~J} / \mathrm{cm}^{2}-600\right.$

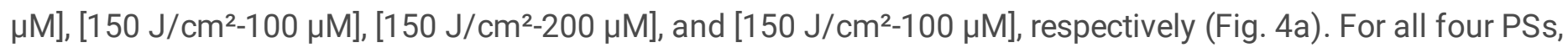
these same combinations provided reductions ranging from 3.92 to $6.11 \log \mathbb{}$ in K. pneumoniae-2 (Fig. 4b).

In the preliminary experiments with $A$. baumannii-1, there was strong photoinactivation at [100 J/cm²-100 $\mu \mathrm{M}]$

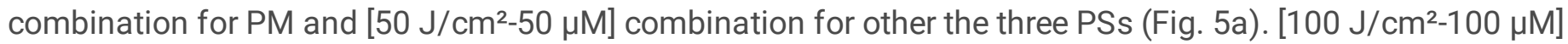
combination using PM provided reductions ranging from 4.43 to $6.58 \log \otimes \mathbb{Q}$ in other clinical isolates except for $A$.

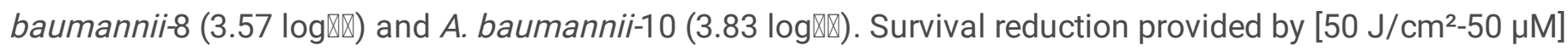
combination using PE, PN, and PL varied from 4.06 to $6.78 \log \otimes \mathbb{Q}$ in other clinical isolates except for $A$. baumannii10 (PN, $3.76 \log \otimes \mathbb{8})$ (Fig. 5b).

Toxicity on the fibroblast cells

The toxicity of the concentrations for each PS used on clinical isolates was investigated on fibroblast cells. Any of PM concentrations at 15 min incubation did not show dark toxic effects on fibroblast cells. $200 \mu \mathrm{M}$ and above of PM concentration at $24 \mathrm{~h}$ incubation resulted in a decrease in survival ranging from 9.52 to $41.99 \%$ (Fig. 6a). PE, which did not show dark toxic effects after 15 min of incubation, caused reductions varying between 18.15 and $32.70 \%$ at $24 \mathrm{~h}$ incubation (Fig. $6 \mathrm{~b}$ ). PN was toxic at $50 \mu \mathrm{M}$ and above concentrations at $15 \mathrm{~min}$ of incubation. All PN concentrations were toxic at $24 \mathrm{~h}$ incubation, and the survival decline ranged from 18.5 to $57.80 \%$ (Fig. $6 \mathrm{c}$ ). At the 15 min of incubation, the toxic effect for PL began at concentrations above $200 \mu \mathrm{M}$. It caused fibroblast cell reductions ranging from 15.38 to $31.95 \%$ at $24 \mathrm{~h}$ incubation (Fig. 6c).

Figure 7 shows the efficacy of the aPDT and light on fibroblast cells. [50 j/cm²-100 $\mathrm{MM}$ ] combination using PM provided $31.43 \%$ and $13.65 \%$ reduction in the fibroblasts at $15 \mathrm{~min}$ and $24 \mathrm{~h}$ incubation, respectively. In other combinations, there was cell reduction at $15 \mathrm{~min}$ of incubation, while cell proliferation varying from 58.96 to 94.82\% occurred at $24 \mathrm{~h}$ incubation (Fig. 7a). For PE and PN, [50 j/cm²-50 $\mu \mathrm{M}]$ at both incubation times did not cause a significant reduction in fibroblast cells compared to other combinations (Fig. 7b and Fig. 7c). There was no significant reduction in any combination of fibroblast cells at both $15 \mathrm{~min}$ and $24 \mathrm{~h}$ incubations for PL (Fig. 7d).

No phototoxicity was observed at any of the incubation periods. On the contrary, proliferation was seen and significant, especially at $100 \mathrm{~J} / \mathrm{cm}^{2}$ and $150 \mathrm{~J} / \mathrm{cm}^{2}$.

\section{Discussions}

In the aPDT application, it is among the primary priorities that the PS can only be activated by light, has a high wavelength absorption capacity, and a maximal level of antimicrobial activity in a wide spectrum (Klausen, Ucuncu, and Bradley 2020; Taslı et al. 2018). In this current study, MIC evaluation results showed that the antimicrobial activities of the CPDs without light were negligible. CPDs provided a strong antimicrobial activity against MDR clinical isolates at concentrations well below the MIC values. With this feature, CPDs met one of the important conditions to be a PS.

Loading [MathJax]/jax/output/CommonHTML/fonts/TeX/fontdata.js 
In pioneering photoinactivation experiments on clinical isolates, PS concentrations ranging from 50-600 $\mu \mathrm{M}$ were required for $3 \log \mathbb{Q}$ and above bacterial reduction. On the other hand, $300 \mu \mathrm{M}$ and above for PM and $200 \mu \mathrm{M}$ and above for PE, PN, and PL at $24 \mathrm{~h}$ incubation caused dark toxicity on the fibroblast cells. This result will limit the use of CPD concentrations of 200 and above in aPDT combinations. However, the finding of increased dark toxicity due to increased CPD concentration was consistent with the literature (Hanakova, Bogdanova, Tomankova, Pizova, et al. 2014; Jimenez-Banzo et al. 2008; Lambrechts et al. 2005; Yuan et al. 2017).

Combinations of aPDT with high PE and PN concentrations and energy density that provided photoinactivation on the clinical isolates resulted in a reduction in survival of up to $50 \%$ in fibroblast cells. However, limited fibroblast reduction (below 13\%) at [50 J/cm²-50 uM] combination for PE and PN may be promising. On the other hand, the photoinactivation efficiency of the combination $\left[50 \mathrm{~J} / \mathrm{cm}^{2}-50 \mathrm{uM}\right]$ against clinical isolates was very low. Contrary to dark toxicity experiments (Fig. 6a and Fig. 6d), at $24 \mathrm{~h}$ incubation, aPDT combinations containing concentrations of $200 \mu \mathrm{M}$ for PL, $300 \mu \mathrm{M}$ and above for PM did not damage fibroblast cells (Fig. 7a and Fig. 7d). The reason for these discordant results may be related to the proliferation effect of light on fibroblast cells. Thus, a significant increase on fibroblast cells was observed at $100 \mathrm{~J} / \mathrm{cm}^{2}$ and $150 \mathrm{~J} / \mathrm{cm}^{2}$ energy density (Fig. 7e). These results were in line with the results that red light induces cell proliferation by increasing the release of essential fibroblast growth factors (Cios et al. 2021; Fortuna et al. 2018; George, Hamblin, and Abrahamse 2018; Kim et al. 2019; Li et al. 2017; Niu et al. 2015; Sperandio et al. 2015; Zhang et al. 2003). However, attributing fibroblast cell proliferation only to the biostimulant effect of light in aPDT application may be an incomplete approach. aPDT application may also have contributed to fibroblast proliferation. However, no research has been found to support or refute this assumption. On the other hand, in most of the research has been reported that the toxic effects of cationic porphyrins on fibroblast cells increase in parallel with the increase in concentration and energy density (Dosselli et al. 2014; Hanakova, Bogdanova, Tomankova, Binder, et al. 2014; Lambrechts et al. 2005; Liu et al. 2012). There were studies in which a strong photoinactivation effect was obtained at PS concentrations much lower than the PS concentrations used in the current study. However, these studies evaluated the efficacy of aPDT against wild-type bacteria (Alenezi et al. 2017; Almeida et al. 2014; Alves et al. 2013; Banfi et al. 2006; Collins et al. 2010; Dosselli et al. 2014; M. C. Gomes et al. 2013; Liu et al. 2012; Maisch et al. 2012; Skwor et al. 2016; Tavares et al. 2010; Tomé et al. 2004) using a blue light source (Banfi et al. 2006; Fila, Kawiak, and Grinholc 2016; Liu et al. 2012; Nitzan and Ashkenazi 2001). In the current study, the requirement for high concentration and energy density for strong photoactivation may be related to the light source used. Red light has more tissue penetration than blue light (Nitzan and Ashkenazi 2001; Taslı et al. 2018). Therefore, the red light was used for CPDs with absorbance values in the range of $250-800 \mathrm{~nm}$ (wavelength average: $422 \pm 3 \mathrm{~nm}$ ). In this current study, the photoinactivation efficacy provided by aPDT combinations in all clinical isolates of each strain was consistent. However, this generalization did not apply to PM. In the aPDT experiments using PM, photoinactivation efficiency decreased between $22.94 \%$ and $32.24 \%$ in some other clinical isolates of the strain. Interestingly, unlike other bacterial species, low energy density and PS concentration provided a strong photoinactivation effect in MDR A. baumannii strains. Further analysis is needed to explain this finding, such as photosensitizing absorption, measurement of ROS, and ${ }^{1} \mathrm{O}_{2}$ formation amounts.

The current research was aimed to determine whether CPDs are ideal PS by pioneering experiments. In particular, PN and PE are not suitable for aPDT at high concentrations and energy density without undergoing modifications that inhibit host cell entry. However, the exciting results regarding PL were promising. Compared with other PSs, aPDTs using PL (5,10,15,20 Tetrakis(N-(3-hydroxypropyl)pyridinium-4yl) porphyrin tetrabromide) had little or no 
toxic effects on fibroblast cells. The presence of the hydroxyl group may have made this difference. Our next step will be to investigate these reasons that make the difference for PSs.

\section{Declarations}

\section{Acknowledgements}

We would like to thank Ege University Scientific Research Projects Coordinator (Project Number:14-ECZ-043) for supporting the research budget. We would like to thank Emel BAKAY for supporting cell culture experiments.

\section{Conflict of Interest}

No conflict of interest declared should appear within this section.

\section{Appendix A. Supplementary data}

Supplementary data to this article can be found on line at ......

\section{Author Contribution}

Research design: Ayşe AKBIYIK, Hüseyin TAŞLI, Nermin TOPALOĞLU

Synthesis of CPDs: Vildan ALPTÜZÜN, Sülünay PARLAR

Identification and investigation of antibiotic susceptibility of clinical isolates: Selçuk KAYA

Evaluation of minimum inhibitory concentrations of CPDs: Ayşe AKBIYIK, Hüseyin TAŞLI

Photoinactivation experiments: Ayşe AKBIYIK, Hüseyin TAŞLI, Nermin TOPALOĞLU

Evaluation of fibroblast toxicity: Ayşe AKBIYIK, Hüseyin TAŞLI, Nermin TOPALOĞLU

Preparing the draft of the article: Ayşe AKBIYIK, Vildan ALPTÜZÜN

Reviewing and evaluating the draft of the article: Ayşe AKBIYIK, Hüseyin TAŞLI, Nermin TOPALOĞLU, Vildan ALPTÜZÜN

\section{References}

1. Aftab S, Tarik MM, Siddique MA, Yusuf MA (2014) Clinical and microbiological aspect of wound infection: a Review Update. Bangladesh Journal of Infectious Diseases 1(2):32-37

2. Alenezi K, Tovmasyan A, Batinic-Haberle I, Benov LT (2017) Optimizing Zn porphyrin-based photosensitizers for efficient antibacterial photodynamic therapy. Photodiagn Photodyn Ther 17:154-159

3. Almeida J, Tomé JP, Neves MG, Tomé AC, Cavaleiro JA, Cunha Â, ... Almeida A (2014) Photodynamic inactivation of multidrug-resistant bacteria in hospital wastewaters: influence of residual antibiotics. Photochem Photobiol Sci 13(4):626-633

4. Alves E, Faustino MA, Tomé JP, Neves MG, Tomé AC, Cavaleiro JA, ... Almeida A (2013) Nucleic acid changes during nhotodvnamic inactivation of hacteria hv cationic porphyrins. Bioorg Med Chem 21(14):4311-4318

Loading [MathJax]/jax/output/CommonHTML/fonts/TeX/fontdata.js 
5. Alves E, Faustino MA, Neves MG, Cunha A, Tome J, Almeida A (2014) An insight on bacterial cellular targets of photodynamic inactivation. Future medicinal chemistry 6(2):141-164

6. Amos-Tautua BM, Songca SP, Oluwafemi OS (2019) Application of porphyrins in antibacterial photodynamic therapy. Molecules 24(13):2456

7. Banfi S, Caruso E, Buccafurni L, Battini V, Zazzaron S, Barbieri P, Orlandi V (2006) Antibacterial activity of tetraaryl-porphyrin photosensitizers: an in vitro study on Gram negative and Gram positive bacteria. Journal of photochemistry photobiology B: Biology 85(1):28-38

8. Braga IA, Ribas RM, Filho G, P. P., \& Filho D, A (2013) Bacterial colonization of pressure ulcers: assessment of risk for bloodstream infection and impact on patient outcomes. J Hosp Infect 83(4):314-320

9. Carpenter BL, Feese E, Sadeghifar H, Argyropoulos DS, Ghiladi RA (2012) Porphyrin-cellulose nanocrystals: a photobactericidal material that exhibits broad spectrum antimicrobial activity. Photochemistry photobiology 88(3):527-536

10. Cios A, Cieplak M, Szymański Ł, Lewicka A, Cierniak S, Stankiewicz W, ... Lewicki S (2021) Effect of Different Wavelengths of Laser Irradiation on the Skin Cells. Int J Mol Sci 22(5):2437

11. Collins TL, Markus EA, Hassett DJ, Robinson JB (2010) The effect of a cationic porphyrin on Pseudomonas aeruginosa biofilms. Current microbiology 61(5):411-416

12. Daeschlein G, von Woedtke T, Kindel E, Brandenburg R, Weltmann KD, Jünger M (2010) Antibacterial activity of an atmospheric pressure plasma jet against relevant wound pathogens in vitro on a simulated wound environment. Plasma Processes Polym 7(3-4):224-230

13. Dai T, Huang YY, Hamblin MR (2009) Photodynamic therapy for localized infections-state of the art. Photodiagn Photodyn Ther 6(3-4):170-188

14. Dosselli R, Ruiz-Gonzalez R, Moret F, Agnolon V, Compagnin C, Mognato M, ... Reddi E (2014) Synthesis, spectroscopic, and photophysical characterization and photosensitizing activity toward prokaryotic and eukaryotic cells of porphyrin-magainin and-buforin conjugates. Journal of medicinal chemistry 57(4):14031415

15. Fila G, Kawiak A, Grinholc MS (2017) Blue light treatment of Pseudomonas aeruginosa: Strong bactericidal activity, synergism with antibiotics and inactivation of virulence factors. Virulence 8(6):938-958

16. Fortuna T, Gonzalez AC, Sá MF, Andrade ZDA, Reis SR, Medrado AR (2018) Effect of $670 \mathrm{~nm}$ laser photobiomodulation on vascular density and fibroplasia in late stages of tissue repair. International wound journal 15(2):274-282

17. George S, Hamblin MR, Abrahamse H (2018) Effect of red light and near infrared laser on the generation of reactive oxygen species in primary dermal fibroblasts. J Photochem Photobiol B 188:60-68

18. Gomes MC, Silva S, Faustino MA, Neves MG, Almeida A, Cavaleiro JA, ... Cunha Â (2013) Cationic galactoporphyrin photosensitisers against UV-B resistant bacteria: oxidation of lipids and proteins by 102 . Photochem Photobiol Sci 12(2):262-271

19. Gomes MC, Woranovicz-Barreira SM, Faustino MA, Fernandes R, Neves MG, Tomé AC, ... Tomé JP (2011) Photodynamic inactivation of Penicillium chrysogenum conidia by cationic porphyrins. Photochem Photobiol Sci 10(11):1735-1743

20. Hamblin MR, Hasan T (2004) Photodynamic therapy: a new antimicrobial approach to infectious disease? Photochem Photobiol Sci 3(5):436-450 
21. Hanakova A, Bogdanova K, Tomankova K, Binder S, Bajgar R, Langova K, ... Kolarova H (2014) Study of photodynamic effects on NIH 3T3 cell line and bacteria. Biomed Pap Med Fac Univ Palacky Olomouc Czech Repub 158(2):201-207

22. Hanakova A, Bogdanova K, Tomankova K, Pizova K, Malohlava J, Binder S, ... Kolarova H (2014) The application of antimicrobial photodynamic therapy on $\mathrm{S}$. aureus and $\mathrm{E}$. coli using porphyrin photosensitizers bound to cyclodextrin. Microbiological research 169(2-3):163-170

23. Stojiljkovic I, Evavold BD, Kumar V (2001) Antimicrobial properties of porphyrins. Expert opinion on investigational drugs 10(2):309-320

24. Institute $C$ and Laboratory Standards (2018) "Performance Standards for Antimicrobial Susceptibility Testing." 28th ed. Supplement M100, Wayne, Pa

25. Jiménez-Banzo A, Sagristà ML, Mora M, Nonell S (2008) Kinetics of singlet oxygen photosensitization in human skin fibroblasts. Free Radic Biol Med 44(11):1926-1934

26. Kim YK, Kim JH, Jo YH, Lee JS (2019) Precipitating metal nitrate deposition of amorphous metal oxyhydroxide electrodes containing $\mathrm{Ni}$, Fe, and Co for electrocatalytic water oxidation. ACS Catalysis 9(10):9650-9662

27. Klausen M, Ucuncu M, Bradley M (2020) Design of Photosensitizing Agents for Targeted Antimicrobial Photodynamic Therapy. Molecules 25(22):5239

28. Lambrechts SA, Schwartz KR, Aalders MC, Dankert JB (2005) Photodynamic inactivation of fibroblasts by a cationic porphyrin. Lasers in medical science 20(2):62-67

29. Li X, Liu Z, Liu H, Chen X, Liu Y, Tan H (2017) Photodynamic inactivation of fibroblasts and inhibition of Staphylococcus epidermidis adhesion and biofilm formation by toluidine blue O. Mol Med Rep 15(4):18161822

30. Lippert R, Shubina TE, Vojnovic S, Pavic A, Veselinovic J, Nikodinovic-Runic J, ... Ivanović-Burmazović I (2017) Redox behavior and biological properties of ferrocene bearing porphyrins. J Inorg Biochem 171:76-89

31. Liu F, Soh Yan Ni A, Lim Y, Mohanram H, Bhattacharjya S, Xing B (2012) Lipopolysaccharide neutralizing peptide-porphyrin conjugates for effective photoinactivation and intracellular imaging of Gram-negative bacteria strains. Bioconjugate chemistry 23(8):1639-1647

32. Maisch T, Spannberger F, Regensburger J, Felgenträger A, Bäumler W (2012) Fast and effective: intense pulse light photodynamic inactivation of bacteria. J Ind Microbiol Biotechnol 39(7):1013-1021

33. Nasir NM, Lee BK, Yap SS, Thong KL, Yap SL (2016) Cold plasma inactivation of chronic wound bacteria. Arch Biochem Biophys 605:76-85

34. National Pressure Ulcer Advisory Panel, European Pressure Ulcer Advisory Panel and Pan Pacific Pressure Injury Alliance (2014) Prevention and Treatment of Pressure Ulcers: Quick Reference Guide.

http://www.npuap.org/wp-content/uploads/2014/08/Quick-Reference-Guide-DIGITAL-NPUAP-EPUAP-PPPIAJan2016.pdf

35. Nitzan Y, Ashkenazi H (2001) Photoinactivation of Acinetobacter baumannii and Escherichia coli B by a cationic hydrophilic porphyrin at various light wavelengths. Current microbiology 42(6):408-414

36. Niu T, Tian Y, Cai Q, Ren Q, Wei L (2015) Red light combined with blue light irradiation regulates proliferation and apoptosis in skin keratinocytes in combination with low concentrations of curcumin. PloS one 10(9):e0138754

37. Norman G, Dumville JC, Moore ZE, Tanner J, Christie J, Goto S (2016) Antibiotics and antiseptics for pressure

Loading [MathJax]/jax/output/CommonHTML/fonts/TeX/fontdata.js ?)

Page $12 / 22$ 
38. Prasanth CS, Karunakaran SC, Paul AK, Kussovski V, Mantareva V, Ramaiah D, ... Subhash N (2014) Antimicrobial Photodynamic Efficiency of Novel Cationic Porphyrins towards Periodontal Gram-positive and Gram-negative Pathogenic Bacteria. Photochemistry photobiology 90(3):628-640

39. Ragàs X, He X, Agut M, Roxo-Rosa M, Gonsalves AR, Serra AC, Nonell S (2013) Singlet oxygen in antimicrobial photodynamic therapy: photosensitizer-dependent production and decay in E. coli. Molecules 18(3):27122725

40. Rahimi R, Fayyaz F, Rassa M, Rabbani M (2016) Microwave-assisted synthesis of 5, 10, 15, 20-tetrakis (4nitrophenyl) porphyrin and zinc derivative and study of their bacterial photoinactivation. Quarterly Journal of Iranian Chemical Communication, 4(2, pp. 133-235, Serial No. 11), 175-185

41. Rajesh S, Koshi E, Philip K, Mohan A (2011) Antimicrobial photodynamic therapy: An overview. Journal of Indian Society of Periodontology 15(4):323

42. Reddi E, Ceccon M, Valduga G, Jori G, Bommer JC, Elisei F, ... Mazzucato U (2002) Photophysical Properties and Antibacterial Activity of Meso-substituted Cationic Porphyrins4. Photochem Photobiol 75(5):462-470

43. Siddiqui AR, Bernstein JM (2010) Chronic wound infection: facts and controversies. Clin Dermatol 28(5):519526

44. Skwor TA, Klemm S, Zhang H, Schardt B, Blaszczyk S, Bork MA (2016) Photodynamic inactivation of methicillin-resistant Staphylococcus aureus and Escherichia coli: A metalloporphyrin comparison. J Photochem Photobiol B 165:51-57

45. Sperandio FF, Simões A, Corrêa L, Aranha AC, Giudice FS, Hamblin MR, Sousa SC (2015) Low-level laser irradiation promotes the proliferation and maturation of keratinocytes during epithelial wound repair. Journal of biophotonics 8(10):795-803

46. Taslı H, Akbıyık A, Topaloğlu N, Alptüzün V, Parlar S (2018) Photodynamic antimicrobial activity of new porphyrin derivatives against methicillin resistant Staphylococcus aureus. J Microbiol 56(11):828-837

47. Tavares A, Carvalho C, Faustino MA, Neves MG, Tomé JP, Tomé AC, ... Almeida A (2010) Antimicrobial photodynamic therapy: study of bacterial recovery viability and potential development of resistance after treatment. Marine drugs 8(1):91-105

48. Tavares A, Dias SR, Carvalho CM, Faustino MA, Tomé JP, Neves MG, ... Almeida A (2011) Mechanisms of photodynamic inactivation of a Gram-negative recombinant bioluminescent bacterium by cationic porphyrins. Photochem Photobiol Sci 10(10):1659-1669

49. Tomé JP, Neves MG, Tomé AC, Cavaleiro JA, Soncin M, Magaraggia M, ... Jori G (2004) Synthesis and antibacterial activity of new poly-S-lysine - Porphyrin conjugates. Journal of medicinal chemistry 47(26):6649-6652

50. Topaloğlu N, Kadıköylü G, Onak G, Karaman O (2020) The effect of indocyanine green-based photodynamic therapy on healthy fibroblast and keratinocyte cells. Photodiagn Photodyn Ther 31:101891

51. Yuan Y, Liu ZQ, Jin H, Sun S, Liu TJ, Wang X, ... Ding H (2017) Photodynamic antimicrobial chemotherapy with the novel amino acid-porphyrin conjugate 4I: In vitro and in vivo studies. PloS one 12(5):e0176529

52. Song S, Zhang Y, Fong CC, Tsang CH, Yang Z, Yang M (2003) cDNA microarray analysis of gene expression profiles in human fibroblast cells irradiated with red light. Journal of investigative dermatology 120(5):849857

53. Zoltan T, Vargas F, Rivas C, Lãpez V, Perez J, Biasutto A (2010) Synthesis, photochemical and photoinduced Loading [MathJax]/jax/output/CommonHTML/fonts/TeX/fontdata.js 
pharmaceutica $78(4): 767-789$

\section{Table}

Table 1. Minimal inhibitory concentrations of CPDs and ciprofloxacin

\begin{tabular}{|llllll|}
\hline CPDs and concentration values & E.coli-1 & P. aeruginosa 1 & K.pneumoniae 1 & A.baumannii 1 \\
\hline PM & $\mu \mathrm{g} / \mathrm{mL}$ & 1250 & $>5000$ & 5000 & 2500 \\
\cline { 2 - 2 } & 1841.38 & $>7365.51$ & 7365.51 & 3682.75 \\
\hline $\mathrm{PE}$ & $\mu \mathrm{g} / \mathrm{mL}$ & 625 & 5000 & 5000 & 5000 \\
\hline $\mathrm{PN}$ & 850.40 & 6803.18 & 6803.18 & 6803.18 \\
& $\mu \mathrm{M} / \mathrm{mL}$ & 1250 & 1250 & $>5000$ & 2500 \\
\hline $\mathrm{PL}$ & $\mu \mathrm{M}$ & 1580.16 & 1580.16 & 6320.64 & 3160.32 \\
& $\mu \mathrm{g} / \mathrm{mL}$ & 5000 & 5000 & 2500 & 1250 \\
\hline Ciprofloxacin* & $\mu \mathrm{M}$ & 5847.61 & 5847.61 & 2923.81 & 1461.90 \\
\hline
\end{tabular}

*Acceptable quality control ranges of minimum inhibitory concentrations of ciprofloxacin for reference strains.

\section{Figures}




\section{$\mathbf{a}$}

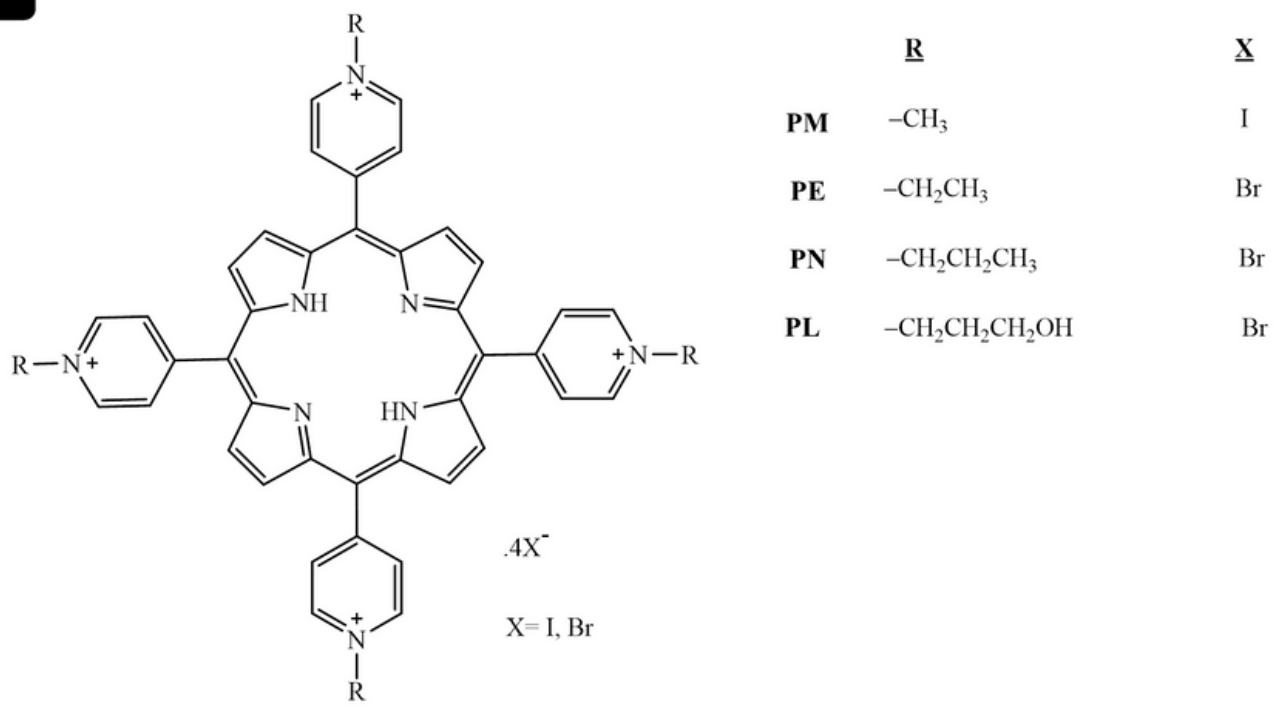

b

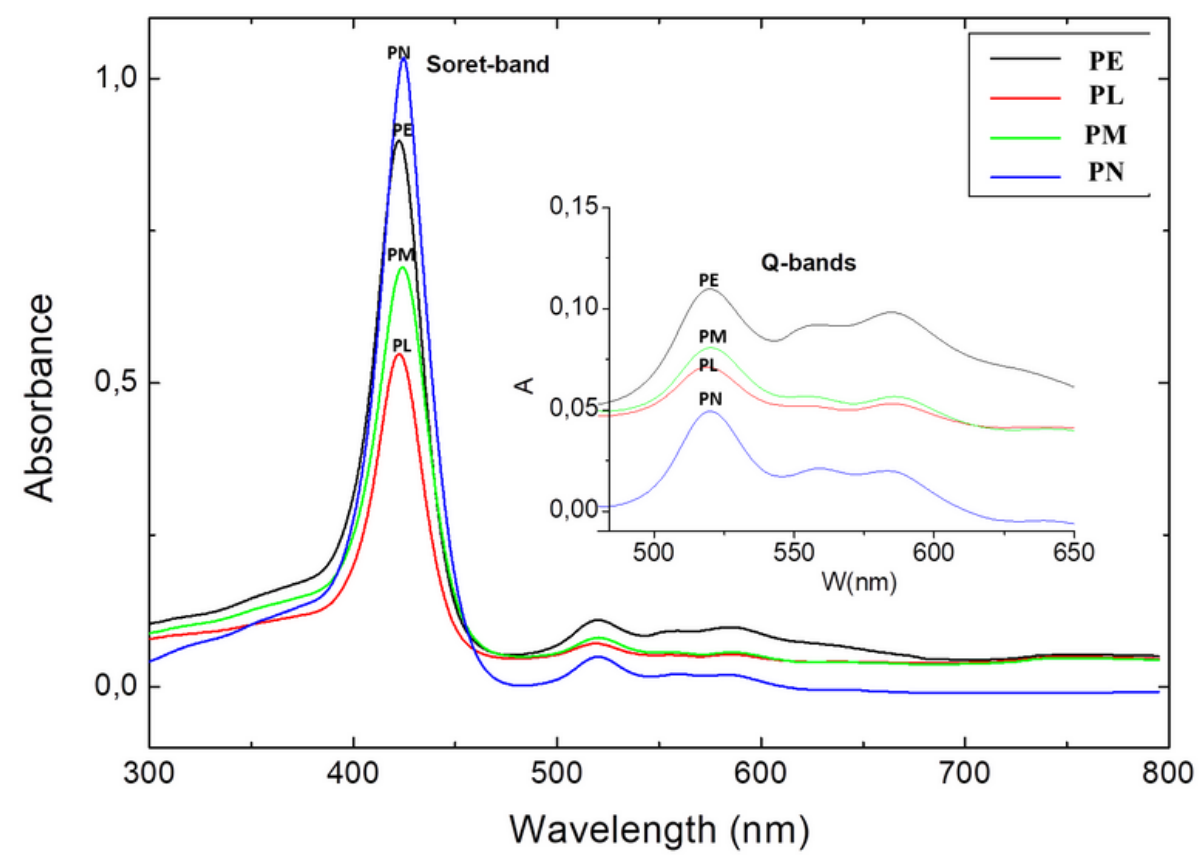

Figure 1

Features of CPDs. a. The chemical structures of CPDs. b. Light absorptions of the CPDs. (Perkin Elmer UV Winlab Data and Vievwer Version 1.1.00). 


\begin{tabular}{|c|c|c|c|c|c|c|c|c|c|}
\hline \multirow[t]{2}{*}{ a } & & \multicolumn{8}{|c|}{ Reduction in survival in APDT groups for E.coli-1 [ $\left.\log _{-10}\right)$} \\
\hline & & $25 \mu \mathrm{M}$ & $50 \mu \mathrm{M}$ & $100 \mu \mathrm{M}$ & $200 \mu \mathrm{M}$ & $300 \mu \mathrm{M}$ & $400 \mu \mathrm{M}$ & $500 \mu \mathrm{M}$ & $600 \mu \mathrm{M}$ \\
\hline \multirow[t]{3}{*}{$\mathbf{P M}$} & $50 \mathrm{~J} / \mathrm{cm}^{2}$ & $0.06 \pm 0.02$ & $0.13 \pm 0.03$ & $0.37 \pm 0.06$ & $0.24 \pm 0.10$ & $0.17 \pm 0.02$ & $0.05 \pm 0.02$ & $0.60 \pm 0.18$ & $1.50 \pm 0.01$ \\
\hline & $100 \mathrm{~J} / \mathrm{cm}^{2}$ & $0.11 \pm 0.00$ & $0.09 \pm 0.05$ & $0.51 \pm 0.01$ & $0.21 \pm 0.12$ & $1.49 \pm 0.05$ & $2.74 \pm 0.03$ & $2.98 \pm 0.00$ & $4.46 \pm 0.10$ \\
\hline & $150 \mathrm{~J} / \mathrm{cm}^{2}$ & & & $2.30 \pm 0.02$ & $4.86 \pm 0.09$ & $5.16 \pm 0.12$ & $5.58 \pm 0.22$ & $5.80 \pm 0.14$ & \\
\hline \multirow[t]{3}{*}{ PE } & $50 \mathrm{~J} / \mathrm{cm}^{2}$ & $-.69 \pm 0.41$ & $0.08 \pm 0.02$ & $0.69 \pm 0.03$ & $1.56 \pm 0.15$ & $2.63 \pm 0.11$ & $4.08 \pm 0.04$ & & \\
\hline & $100 \mathrm{~J} / \mathrm{cm}^{2}$ & & & $2.90 \pm 0.12$ & $3.61 \pm 0.11$ & $4.52 \pm 0.09$ & & & \\
\hline & $150 \mathrm{~J} / \mathrm{cm}^{2}$ & & $2.90 \pm 0.12$ & $4.62 \pm 0.01$ & $5.71 \pm 0.26$ & & & & \\
\hline \multirow[t]{3}{*}{ PN } & $50 \mathrm{~J} / \mathrm{cm}^{2}$ & $0.43 \pm 0.02$ & $0.46 \pm 0.14$ & $1.03 \pm 0.39$ & $2.29 \pm 0.01$ & $3.22 \pm 0.04$ & $4.01 \pm 0.10$ & & \\
\hline & $100 \mathrm{~J} / \mathrm{cm}^{2}$ & & & $2.69 \pm 0.11$ & $3.65 \pm 0.12$ & $4.39 \pm 0.21$ & & & \\
\hline & $150 \mathrm{~J} / \mathrm{cm}^{2}$ & & $2.32 \pm 0.29$ & $3.71 \pm 0.13$ & $4.73 \pm 0.26$ & & & & \\
\hline \multirow[t]{3}{*}{ PL } & $50 \mathrm{~J} / \mathrm{cm}^{2}$ & $0.62 \pm 0.21$ & $0.84 \pm 0.09$ & $1.93 \pm 0.04$ & $2.36 \pm 0.22$ & $3.54 \pm 0.02$ & $4.23 \pm 0.07$ & & \\
\hline & $100 \mathrm{~J} / \mathrm{cm}^{2}$ & & & $2.64 \pm 0.01$ & $3.33 \pm 0.33$ & $4.58 \pm 0.18$ & & & \\
\hline & $150 \mathrm{~J} / \mathrm{cm}^{2}$ & & $2.47 \pm 0.18$ & $4.57 \pm 0.29$ & $5.23 \pm 0.01$ & & & & \\
\hline
\end{tabular}

b
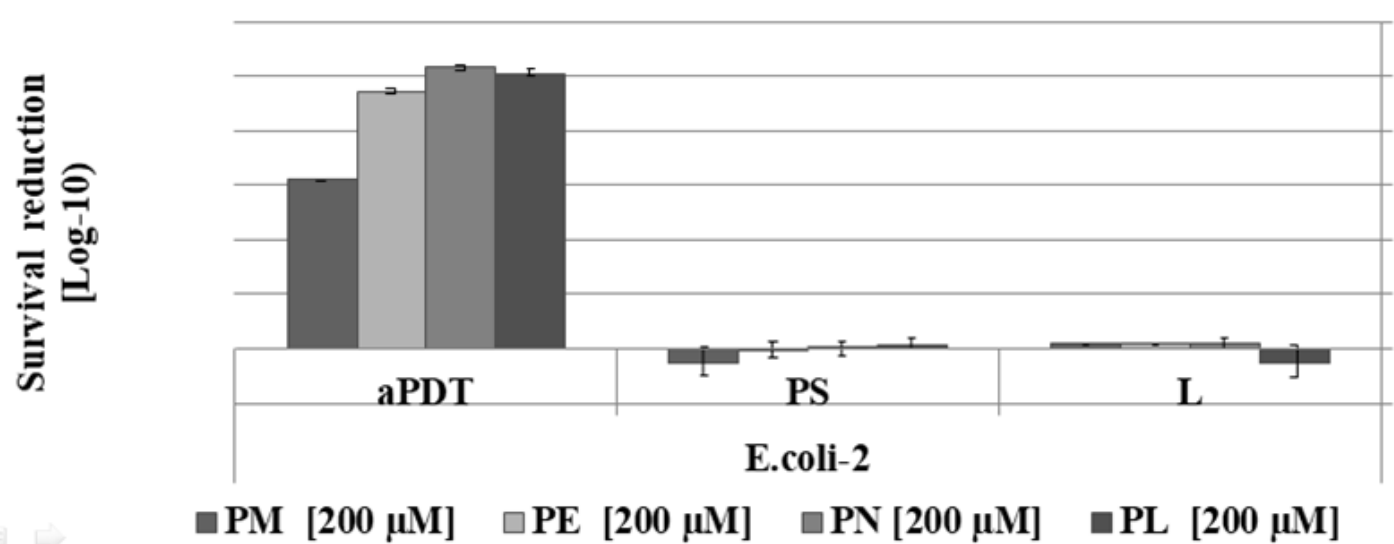

6.00

5.00

4.00

3.00

2.00

1.00

0.00

$-1.00$

Figure 2

The photoinactivation results for MDR E. coli. a. Reduction of MDR E.coli-1 survival at the combinations formed by different energy density and PS concentrations $\mathrm{b}$. The photoinactivation results of the selected combinations at $150 \mathrm{~J} / \mathrm{cm}^{2}$ for MDR E.coli-2. 


\begin{tabular}{|c|c|c|c|c|c|c|c|c|c|}
\hline \multirow[t]{2}{*}{ a } & & \multicolumn{8}{|c|}{ Reduction in survival in APDT groups for P.aeruginosa-1 [ $\left.\log _{-10}\right)$} \\
\hline & & $25 \mu \mathrm{M}$ & $50 \mu \mathrm{M}$ & $100 \mu \mathrm{M}$ & $200 \mu \mathrm{M}$ & $300 \mu \mathrm{M}$ & $400 \mu \mathrm{M}$ & $500 \mu \mathrm{M}$ & $600 \mu \mathrm{M}$ \\
\hline \multirow[t]{3}{*}{$\mathbf{P M}$} & $50 \mathrm{~J} / \mathrm{cm}^{2}$ & $-1.26 \pm 0.88$ & $-1.15 \pm 0.62$ & $-0.19 \pm 0.46$ & $-0.70 \pm 0.25$ & $0.47 \pm 0.04$ & $1.11 \pm 0.01$ & $1.48 \pm 0.02$ & $1.86 \pm 0.04$ \\
\hline & $100 \mathrm{~J} / \mathrm{cm}^{2}$ & $-0.31 \pm 0.10$ & $-0.27 \pm 0.14$ & $0.83 \pm 0.15$ & $0.68 \pm 0.27$ & $1.72 \pm 0.01$ & $2.52 \pm 0.04$ & $3.37 \pm 0.02$ & $5.00 \pm 0.01$ \\
\hline & $150 \mathrm{~J} / \mathrm{cm}^{2}$ & & & & & $2.57 \pm 0.01$ & $3.30 \pm 0.05$ & $4.02 \pm 0.06$ & \\
\hline \multirow[t]{3}{*}{$\mathbf{P E}$} & $50 \mathrm{~J} / \mathrm{cm}^{2}$ & $0.01 \pm 0.10$ & $-0.04 \pm 0.06$ & $1.05 \pm 0.03$ & $2.11 \pm 0.06$ & $3.06 \pm 0.45$ & $4.96 \pm 0.23$ & & \\
\hline & $100 \mathrm{~J} / \mathrm{cm}^{2}$ & & $1.72 \pm 0.14$ & $3.30 \pm 0.24$ & $4.17 \pm 0.06$ & $5.02 \pm 0.09$ & & & \\
\hline & $150 \mathrm{~J} / \mathrm{cm}^{2}$ & & $2.89 \pm 0.01$ & $3.53 \pm 0.04$ & $5.82 \pm 0.02$ & & & & \\
\hline \multirow[t]{3}{*}{$\mathbf{P N}$} & $50 \mathrm{~J} / \mathrm{cm}^{2}$ & $0.24 \pm 0.11$ & $0.86 \pm 0.07$ & $1.73 \pm 0.02$ & $2.86 \pm 0.03$ & $3.68 \pm 0.02$ & $4.01 \pm 0.91$ & & \\
\hline & $100 \mathrm{~J} / \mathrm{cm}^{2}$ & & & $2.68 \pm 0.09$ & $3.27 \pm 0.09$ & $4.07 \pm 0.10$ & & & \\
\hline & $150 \mathrm{~J} / \mathrm{cm}^{2}$ & & $2.59 \pm 0.07$ & $3.32 \pm 0.09$ & $4.42 \pm 0.08$ & & & & \\
\hline \multirow[t]{3}{*}{ PL } & $50 \mathrm{~J} / \mathrm{cm}^{2}$ & $1.09 \pm 0.06$ & $2.43 \pm 0.12$ & $3.98 \pm 0.01$ & $5.11 \pm 0.05$ & & & & \\
\hline & $100 \mathrm{~J} / \mathrm{cm}^{2}$ & $2.46 \pm 0.13$ & $3.84 \pm 0.03$ & $4.69 \pm 0.10$ & & & & & \\
\hline & $150 \mathrm{~J} / \mathrm{cm}^{2}$ & $3.08 \pm 0.05$ & $4.36 \pm 0.07$ & & & & & & \\
\hline
\end{tabular}
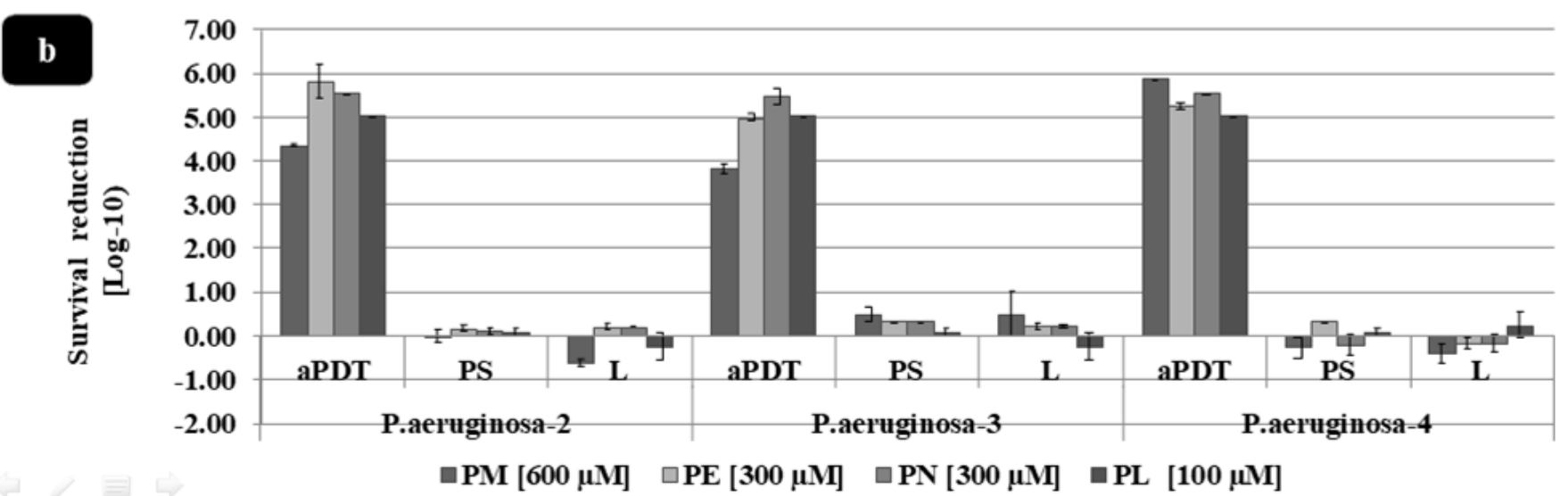

\section{Figure 3}

The photoinactivation results for MDR P.aeruginosa. Reduction of MDR P.aeruginosa-1 survival at the combinations formed by different energy density and PS concentrations $b$. The photoinactivation results of the selected combinations at $100 \mathrm{~J} / \mathrm{cm}^{2}$ for other MDR P.aeruginosa isolates. 


\begin{tabular}{|c|c|c|c|c|c|c|c|c|c|}
\hline \multirow[t]{2}{*}{ a } & & \multicolumn{8}{|c|}{ Reduction in survival in APDT groups for K.pneumoniae-1 [ Log $_{-10}$ ) } \\
\hline & & $25 \mu \mathrm{M}$ & $50 \mu \mathrm{M}$ & $100 \mu \mathrm{M}$ & $200 \mu \mathrm{M}$ & $300 \mu \mathrm{M}$ & $400 \mu \mathrm{M}$ & $500 \mu \mathrm{M}$ & $600 \mu \mathrm{M}$ \\
\hline \multirow[t]{3}{*}{ PM } & $50 \mathrm{~J} / \mathrm{cm}^{2}$ & $-0.21 \pm 0.15$ & $-0.18 \pm 0.08$ & $0.08 \pm 0.03$ & $-0.24 \pm 0.07$ & $0.32 \pm 0.05$ & $0.12 \pm 0.05$ & $0.83 \pm 0.03$ & $1.15 \pm 0.08$ \\
\hline & $100 \mathrm{~J} / \mathrm{cm}^{2}$ & $0.58 \pm 0.07$ & $-0.03 \pm 0.12$ & $0.58 \pm 0.23$ & $0.77 \pm 0.05$ & $0.94 \pm 0.02$ & $1.47 \pm 0.04$ & $2.04 \pm 0.02$ & $3.11 \pm 0.06$ \\
\hline & $150 \mathrm{~J} / \mathrm{cm}^{2}$ & & & & & & $2.86 \pm 0.04$ & $3.24 \pm 0.06$ & $4.83 \pm 0.06$ \\
\hline \multirow[t]{3}{*}{ PE } & $50 \mathrm{~J} / \mathrm{cm}^{2}$ & $0.23 \pm 0.10$ & $0.76 \pm 0.07$ & $1.99 \pm 0.20$ & $2.93 \pm 0.11$ & $4.52 \pm 0.14$ & & & \\
\hline & $100 \mathrm{~J} / \mathrm{cm}^{2}$ & $2.23 \pm 0.02$ & $2.76 \pm 0.07$ & $3.34 \pm 0.07$ & $4.00 \pm 0.12$ & & & & \\
\hline & $150 \mathrm{~J} / \mathrm{cm}^{2}$ & $2.57 \pm 0.16$ & $3.14 \pm 0.02$ & $4.98 \pm 0.10$ & & & & & \\
\hline \multirow[t]{3}{*}{ PN } & $50 \mathrm{~J} / \mathrm{cm}^{2}$ & $-0.41 \pm 0 . .36$ & $0.45 \pm 0.07$ & $1.28 \pm 0.16$ & $2.48 \pm 0.01$ & $3.07 \pm 0.31$ & $4.68 \pm 0.28$ & & \\
\hline & $100 \mathrm{~J} / \mathrm{cm}^{2}$ & & & $1.87 \pm 0.06$ & $3.26 \pm 0.07$ & $4.61 \pm 0.06$ & & & \\
\hline & $150 \mathrm{~J} / \mathrm{cm}^{2}$ & & & $2.36 \pm 0.06$ & $4.43 \pm 0.16$ & & & & \\
\hline \multirow[t]{3}{*}{ PL } & $50 \mathrm{~J} / \mathrm{cm}^{2}$ & $0.01 \pm 0.22$ & $0.97 \pm 0.03$ & $2.12 \pm 0.02$ & $3.29 \pm 0.09$ & $4.18 \pm 0.09$ & & & \\
\hline & $100 \mathrm{~J} / \mathrm{cm}^{2}$ & & $2.77 \pm 0.06$ & $3.75 \pm 0.07$ & $4.67 \pm 0.12$ & & & & \\
\hline & $150 \mathrm{~J} / \mathrm{cm}^{2}$ & $2.55 \pm 0.02$ & $3.55 \pm 0.11$ & $4.73 \pm 0.24$ & & & & & \\
\hline
\end{tabular}

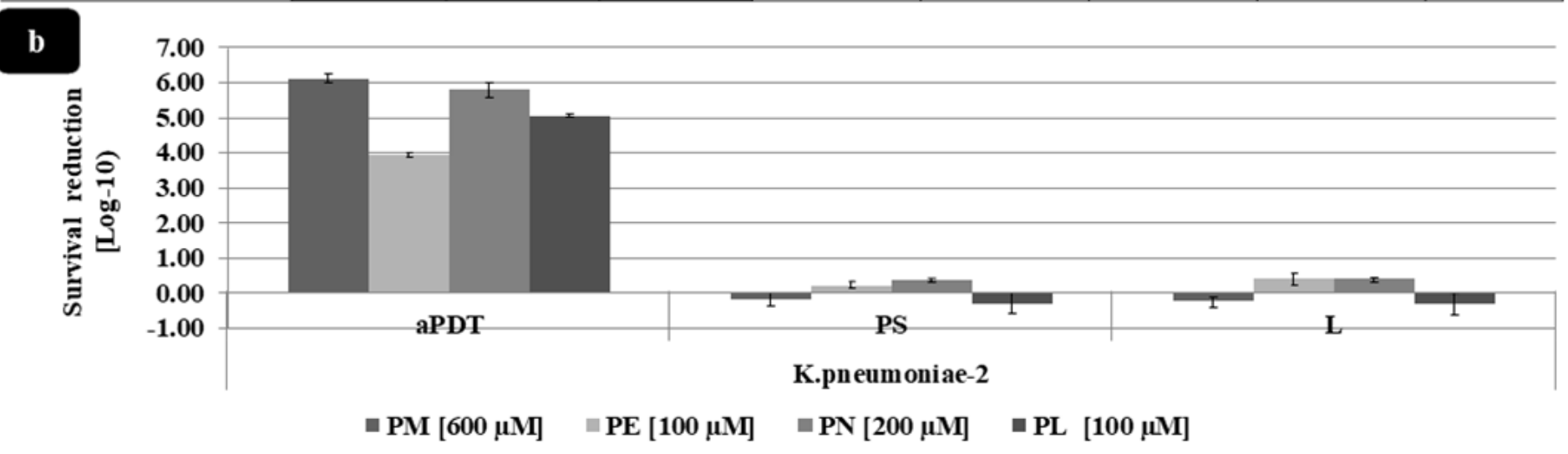

Figure 4

The photoinactivation results for MDR K.pneumoniae. Reduction of MDR K.pneumoniae-1 survival at the combinations formed by different energy density and PS concentrations $b$. The photoinactivation results of the selected combinations at $100 \mathrm{~J} / \mathrm{cm}^{2}$ for MDR K.pneumoniae-2. 


\begin{tabular}{|c|c|c|c|c|c|c|c|c|}
\hline & & \multicolumn{7}{|c|}{ Reduction insurvivalin APDT groups for.A.baumannï-1 [Log-ı] } \\
\hline & & $3.125 \mu \mathrm{M}$ & $6.25 \mu \mathrm{M}$ & $12.50 \mu \mathrm{M}$ & $25 \mu \mathrm{M}$ & $50 \mu \mathrm{M}$ & $100 \mu \mathrm{M}$ & $200 \mu \mathrm{M}$ \\
\hline \multirow[t]{3}{*}{ PM } & $50 \mathrm{~J} / \mathrm{cm}^{2}$ & & & & $0.31 \div 0.10$ & $0.57 \pm 0.21$ & $2.44 \pm 0.07$ & $4.56 \pm 0.08$ \\
\hline & $100 \mathrm{~J} / \mathrm{cm}^{2}$ & & & & & $2.38 \pm 0.11$ & $4.12 \pm 0.38$ & \\
\hline & $150 \mathrm{~J} / \mathrm{cm}^{2}$ & & & & & $2.89 \div 0.18$ & & \\
\hline \multirow[t]{3}{*}{ PE } & $50 \mathrm{~J} / \mathrm{cm}^{2}$ & $0.13 \pm 0.11$ & $1.27 \pm 0.09$ & $2.13 \pm 0.11$ & $3.95 \pm 0.03$ & $5.78 \pm 0.06$ & & \\
\hline & $100 \mathrm{~J} / \mathrm{cm}^{2}$ & & & $2.84 \pm 0.08$ & $4.05 \pm 0.07$ & & & \\
\hline & $150 \mathrm{~J} / \mathrm{cm}^{2}$ & $3.34 \pm 0.08$ & $4.49 \pm 0.07$ & $5.18 \pm 0.01$ & & & & \\
\hline \multirow[t]{3}{*}{ PN } & $50 \mathrm{~J} / \mathrm{cm}^{2}$ & $0.25 \pm 0.12$ & $1.31 \pm 0.11$ & $2.90 \pm 0.07$ & $3.52 \pm 0.19$ & $5.42 \pm 0.02$ & & \\
\hline & $100 \mathrm{~J} / \mathrm{cm}^{2}$ & & $2.05 \pm 0.13$ & $4.21 \pm 0.11$ & $5.03 \pm 0.07$ & & & \\
\hline & $150 \mathrm{~J} / \mathrm{cm}^{2}$ & $3.84 \pm 0.42$ & $4.40 \pm 0.06$ & $5.53 \pm 0.07$ & & & & \\
\hline \multirow[t]{3}{*}{ PL } & $50 \mathrm{~J} / \mathrm{cm}^{2}$ & $0.78 \pm 0.24$ & $1.82 \pm 0.17$ & $2.35 \pm 0.08$ & $3.83 \pm 0.04$ & $5.74 \pm 0.03$ & & \\
\hline & $100 \mathrm{~J} / \mathrm{cm}^{2}$ & & $2.32 \pm 0.09$ & $3.68 \pm 0.14$ & $4.89 \pm 0.04$ & & & \\
\hline & $150 \mathrm{~J} / \mathrm{cm}^{2}$ & & $2.99 \pm 0.25$ & $4.73 \pm 0.06$ & & & & \\
\hline
\end{tabular}
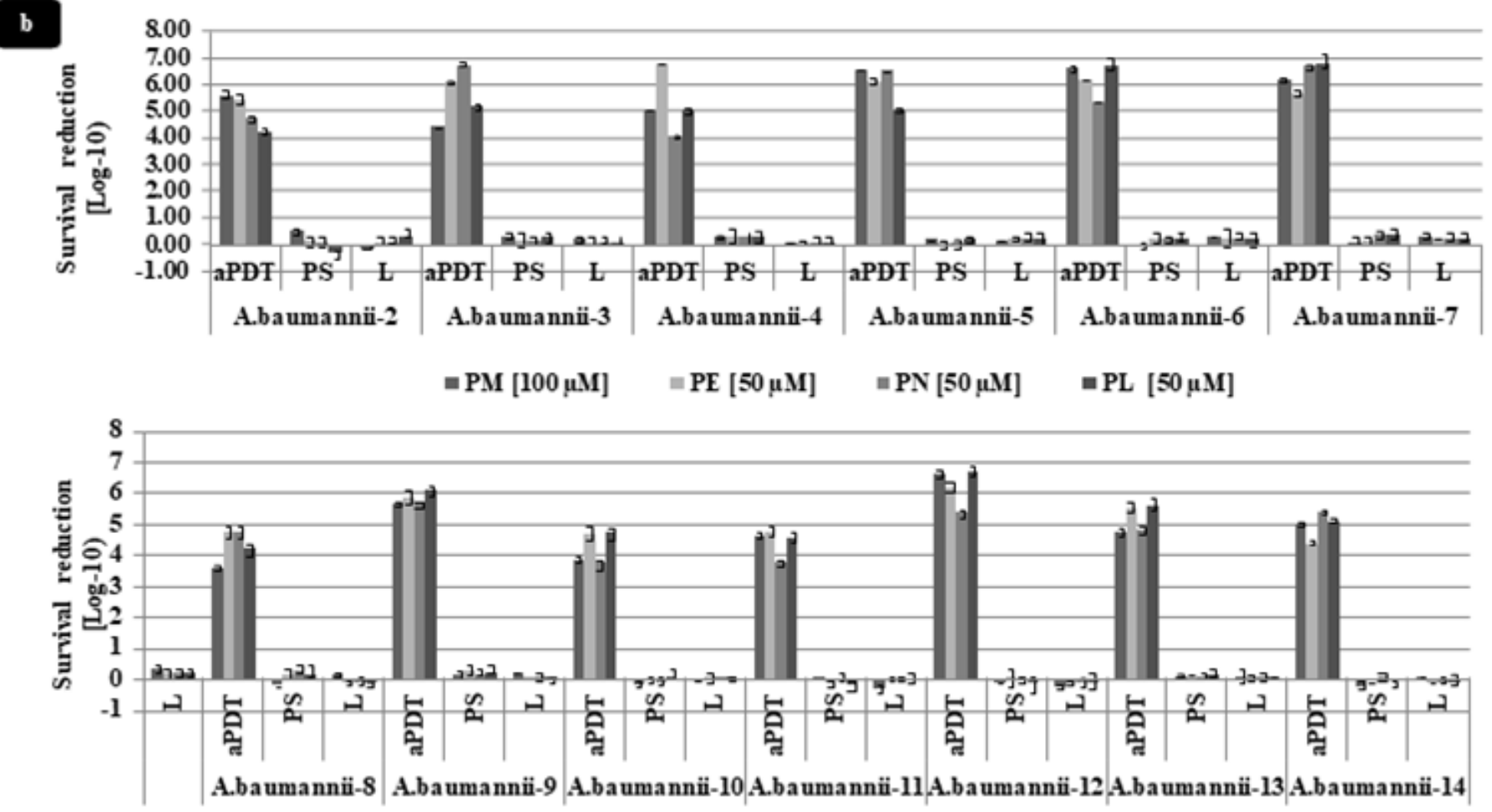

$\|\mathrm{PM}[100 \mu \mathrm{M}] \quad \mathrm{PE}[50 \mu \mathrm{M}]\| \mathrm{PN}[50 \mu \mathrm{M}] \quad \square \mathrm{PL}[50 \mu \mathrm{M}]$

\section{Figure 5}

The photoinactivation results for MDR A.baumannii. Reduction of MDR A.baumannii-1 survival at the combinations formed by different energy density and PS concentrations $b$. The photoinactivation results of the selected combinations at $50 \mathrm{~J} / \mathrm{cm}^{2}$ for other MDR A.baumannii isolates. 
a

PM

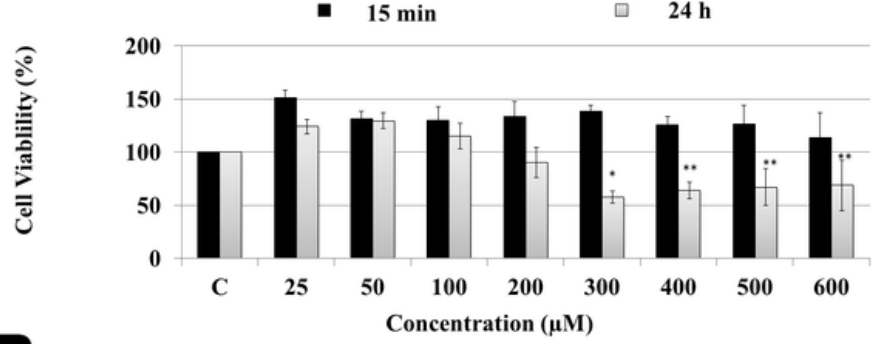

b

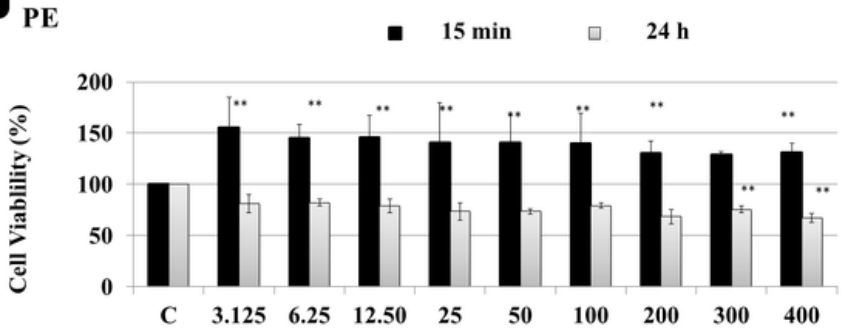

Concentration $(\mu \mathrm{M})$
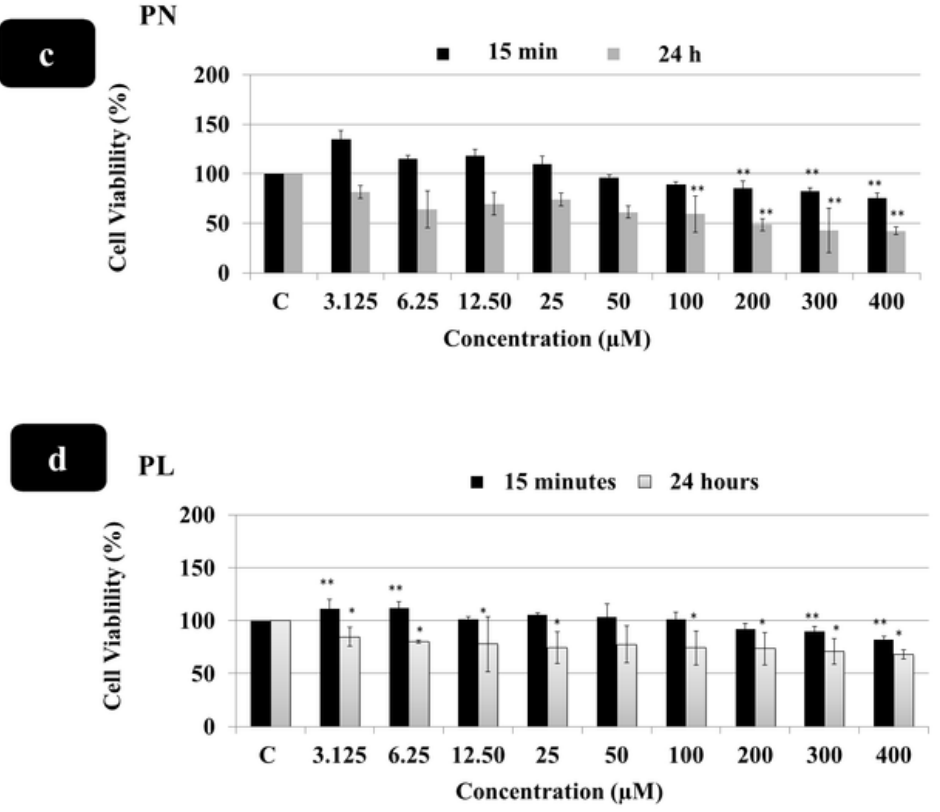

Figure 6

Dark toxicity on the fibroblast cells. a. Cell viability at $25 \mu \mathrm{M}-600 \mu \mathrm{M}$ PM concentrations. b. Cell viability at 3.125 $\mu \mathrm{M}-400 \mu \mathrm{M}$ PE concentrations. c. Cell viability at $3.125 \mu \mathrm{M}-400 \mu \mathrm{M}$ PN concentrations. d. Cell viability at $3.125 \mu \mathrm{M}-$ $400 \mu \mathrm{M}$ PL concentrations ( ${ }^{*} \mathrm{p}<0.01,{ }^{*} \mathrm{p}<0.001$, significant difference versus the control group). 
a

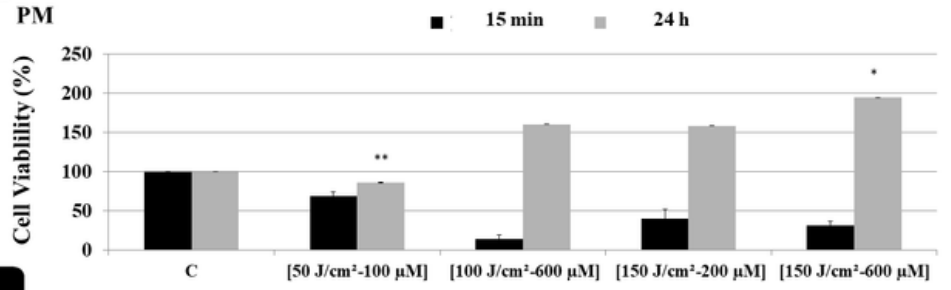

b

PE

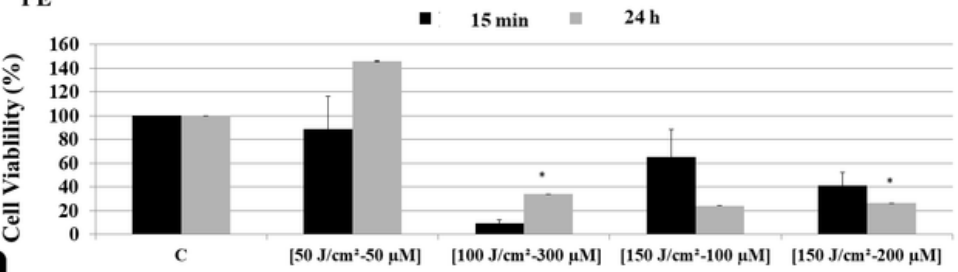

c
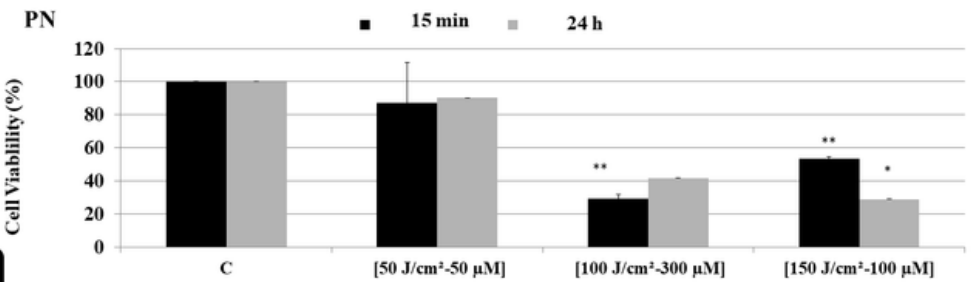

d

- $15 \mathrm{~min} \quad 24 \mathrm{~h}$
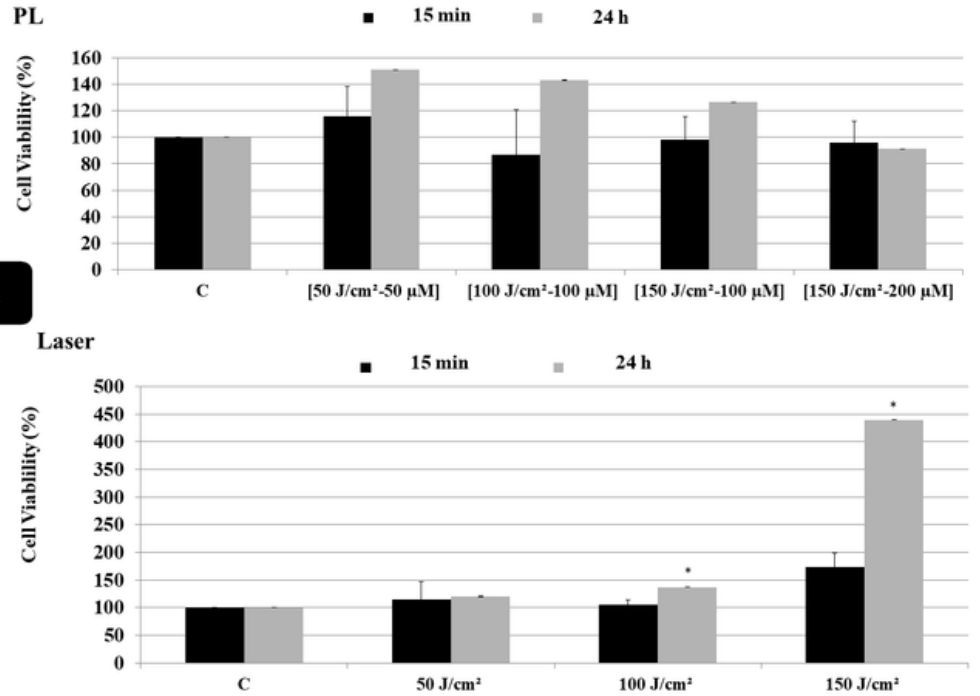

Figure 7

Cytotoxicity and photo toxicity of the aPDT combinations on fibroblast cells. a. Cell viability at aPDT combinations using PM. b. Cell viability at aPDT combinations using PE. c. Cell viability at aPDT combinations using PL. d. Cell viability at aPDT combinations using PN. e. Cell viability at an energy density of $50 \mathrm{~J} / \mathrm{cm}^{2}, 100 \mathrm{~J} / \mathrm{cm}^{2}$ and 150 $\mathrm{J} / \mathrm{cm}^{2}\left({ }^{\star} \mathrm{p}<0.01,{ }^{\star \star} \mathrm{p}<0.001\right.$, significant difference versus the control group).

\section{Supplementary Files}

This is a list of supplementary files associated with this preprint. Click to download.

Loading [MathJax]/jax/output/CommonHTML/fonts/TeX/fontdata.js

Page $21 / 22$ 
- Supplementary1.docx

- Supplementary2.docx 